\title{
The effects of active labour market policies for immigrants receiving social assistance in Denmark
}

\author{
Eskil Heinesen $^{1 *}$, Leif Husted ${ }^{2}$ and Michael Rosholm ${ }^{3}$
}

\footnotetext{
* Correspondence: esh@rff.dk ${ }^{1}$ Rockwool Foundation Research Unit, Sølvgade 10, DK-1307, Copenhagen K, Denmark Full list of author information is available at the end of the article
}

\begin{abstract}
We estimate the effect of active labour-market programmes on the exit rate to regular employment for non-western immigrants in Denmark who receive social assistance. We use the timing-of-events duration model and rich administrative data. We find large positive post-programme effects, and, surprisingly, even most in-programme effects are positive. The effects are largest for subsidized employment programmes, but effects are also large and significant for direct employment programmes and other programmes. Effects are larger if programmes begin after six months of unemployment. Implications of our estimates are illustrated by calculating effects on the duration to regular employment over a five-year period.
\end{abstract}

JEL classification codes: J64, J24, J68, J61, C41

Keywords: Programme evaluation; Duration analysis; Timing-of-events model

\section{Springer}

\section{Introduction}

In most European countries employment rates of non-western immigrants are very low compared to employment rates of natives (OECD 2005), and this has become a major policy issue because of the important consequences for aggregate labour supply, economic growth and the long-run fiscal sustainability issues. Furthermore, it is often argued that labour market integration of immigrants may be important for social integration and cohesion, and there may be long-term effects through integration of children of immigrants.

In this paper, we investigate the effect of active labour market programmes (ALMPs) on the duration until regular employment for non-western immigrants in Denmark receiving social assistance (cash benefits). ${ }^{1}$ The reason why we focus on social assistance recipients is that the majority of non-western immigrants in Denmark are not members of an unemployment insurance fund, implying that they are not entitled to unemployment insurance benefits when they become unemployed; instead they receive social assistance, and they are heavily over-represented among social assistance recipients, especially among long-term recipients. For instance, in 1998 (the second year of our estimation period) immigrants from non-western countries made up $4.8 \%$ of the population and received $38 \%$ of the total amount of social assistance benefits; see Pedersen (2000). Immigrants from western countries are much more similar to natives in terms of labour market attachment and only few receive social assistance benefits.

(C) 2013 Heinesen et al.; licensee Springer. This is an Open Access article distributed under the terms of the Creative Commons Attribution License (http://creativecommons.org/licenses/by/2.0), which permits unrestricted use, distribution, and reproduction in any medium, provided the original work is properly cited. 
Like other recipients of social assistance in Denmark, immigrants are offered active labour market programmes administered by the job centres. Because a large fraction of non-western immigrants are social assistance recipients, it is very important to assess whether these programmes have positive effects on immigrants' employment prospects. If some programmes show positive effects, further targeting of such programmes to immigrants may have large positive effects on labour market integration and, indirectly, on social integration in general.

We use rich administrative data covering all immigrants in Denmark, and we employ the timing-of-events duration model of Abbring and van den Berg (2003). ${ }^{2}$ We find large positive post-programme effects, and, surprisingly, most in-programme effects are positive too. We find the largest effects for subsidized employment programmes, but effects are also large and significant for direct employment programmes as well as for other programmes. Effects are larger for programmes beginning after six months of unemployment. Implications of our estimates are illustrated by calculating marginal effects on the expected duration to regular employment over a five-year period for typical starting times and programme durations. Subsidized employment programmes shorten the social assistance spell by about 10 months for women and 15 months for men. The effect of direct employment programmes is 3.7 months for women and 4.6 months for men, and the effect of other programmes is 1.5 month for women and 2.6 months for men.

Only very few papers have investigated the effects of ALMPs specifically for immigrants, but most of these studies find large and positive effects; see the survey in Rinne (2012). The study most closely related to this paper is Clausen et al. (2009) which investigate effects of programmes offered to newly arrived nonwestern immigrants in Denmark. This is a much smaller and very different group of immigrants compared to the sample of the present paper where more than $60 \%$ had been living in Denmark for more than 5 years. Effects of ALMPs may be very different for immigrants receiving social assistance 5, 10 or 20 years after immigration than for newly arrived immigrants who are offered ALMPs as part of an 'introduction programme'. The former group is much more selective and may have more serious social problems and health problems. Clausen et al. (2009) find that post-programme effects on the hazard rate to regular employment of newly arrived immigrants are significantly positive for wage subsidy programmes, but not for other types of programmes. Bolvig et al. (2003) reach a similar conclusion investigating effects of ALMPs for social assistance recipients in the second largest municipality in Denmark, but they do not estimate separate effects for natives and immigrants.

The overall finding in previous studies on programmes for unemployed workers is that earnings effects as well as employment effects are small; see the surveys in Stanley et al. (1999), Heckman et al. (1999), Kluve (2010), and Card et al. (2010). Stanley et al. (1999) summarise the effects of several US programmes. They find that temporary wage subsidy programmes increase the probability of finding jobs in the subsidy period, but not in the long run, and that job search courses and counselling shorten unemployment duration. The surveys in both Stanley et al. (1999) and Heckman et al. (1999) conclude that effects are heterogeneous: some ALMPs may have positive effects for unemployed with a weak position in the labour market, but for other groups 
the effects are smaller if at all positive. Our findings of rather strong positive effects for non-western immigrants in Denmark are consistent with these previous results, since these immigrants in general have a weak position in the Danish labour market because of language problems and a low level of education or nontransferable education from their country of origin. The findings in the surveys of European labour market programmes by Kluve (2010) and Card et al. (2010) are similar to those for the US: 'private-sector incentive programmes' (including wage subsidies) and 'services and sanctions' (including job search assistance, counselling, and sanctions for non-compliance) typically have positive employment effects, whereas 'traditional labour market training' (including classroom training and onthe-job training) has much smaller and often insignificant effects, and 'direct employment programmes in the public sector' are rarely effective and often have negative employment effects. Card et al. (2010) do show, however, that these negative effects tend to become smaller when effects are studied over a longer time perspective.

Compared to the general findings in the literature, and also compared to the results for newly arrived immigrants in Clausen et al. (2009), our results indicate very large positive ALMP effects for the group of non-western immigrants. This suggests that ALMPs should be applied more extensively for this group than was the case in Denmark during our estimation period. A similar conclusion may apply for other western countries.

This paper is organised as follows. Section 2 describes the institutional setting. Section 3 develops the econometric model. Section 4 describes the data used in the empirical analysis. Section 5 presents the results. Section 6 concludes and discusses policy implications.

\section{Institutional setting}

In Denmark, membership of an unemployment insurance fund is voluntary, and membership of a given fund may be restricted by education and previous employment. Only members will receive UI benefits if they become unemployed. Non-insured workers who become unemployed may instead receive social assistance benefits which are means-tested. As discussed above, we focus on non-insured immigrants in this paper because there are considerably more non-western immigrants who are non-insured than insured, and, in particular, immigrants are over-represented among long-term recipients of social assistance. Therefore, the effect of programmes aimed at labour market integration of non-western immigrants receiving social assistance is of particular interest.

Social assistance recipients will receive ALMP offers from the local authorities, and they have to participate in such a programme in order to remain eligible for social security benefits, which are of unlimited duration. A wide range of ALMPs are being used. In this paper we distinguish between three types: employment with a wage subsidy (mainly in the private sector), direct employment programme (mainly in the public sector), and other programmes which include education, training, and counselling programmes.

According to national law, persons should be offered participation in a programme within 12 months from the beginning of the social-assistance spell. However, there may 
be exemptions in case of serious health problems which may be important for the group of non-western immigrants of which a large share is refugees (about 50\% are refugees or family reunified to a refugee; see Appendix). Participation in ALMPs is described in Section 4.

\section{Econometric model}

We use the timing-of-events duration model of Abbring and van den Berg (2003). We model the duration of the social assistance spell to regular employment simultaneously with the duration from the beginning of the social assistance spell until entry into active labour market programmes. The duration of the social assistance spell includes the time spent in ALMPs. The model takes account of non-random selection into these programmes with respect to observable and unobservable covariates. Assuming mixed proportional hazard $(\mathrm{MPH})$ rates and no anticipation effects, the treatment effects (i.e. the effects of participating in labour market programmes) are non-parametrically identified; see Abbring and van den Berg (2003). The no-anticipation assumption requires that a treatment starting at time $t$ should not affect the outcome state (employment or non-employment) before time $t$. This may be a reasonable assumption in the present application since typically social assistance recipients are not able to predict neither time of treatment nor the specific programme to which they may be assigned until a few days or weeks before programme start (case workers even have the opportunity to assign a programme starting the same day as the meeting with the client). One exception is some types of longer education programmes related to the ordinary education system which only begin a few times per year. Participation in such programmes may in some cases be anticipated a few months in advance, but it is uncommon that immigrants participate in this type of programmes. The kind of education programmes in which immigrants participate are typically a series of shorter courses in the Danish language, in some cases combined with some sort of training programme. Municipalities have a large degree of discretion regarding the timing of treatment, some offer programmes at a very early stage of social assistance receipt, while others typically do not meet the 12-month criterion. In addition, there is a significant variation regarding assignment to ALMPs between case workers within municipalities, and finally programme participation decisions are taken at meetings with case workers, the timing of which is also random to some extent. Thus, the starting times vary a lot for each category of programmes, and for all types of programmes taken together the standard deviation of duration until treatment is 15 months; see Table 1 (which is discussed in detail in the next section). There are general guidelines as to the choice of programme types, but they are rather vague implying that in practice municipalities and case workers have a large degree of discretion also in this respect.

Given the no-anticipation and MPH assumptions, no exclusion restrictions are needed. The intuition behind the identification strategy intrinsic to the timing-of-events model is that there is some random variation in the duration until treatment. This enables a separation between the treatment effect and the unobserved heterogeneity, which is assumed time-invariant. 
Table 1 Descriptive statistics of immigrants' social assistance spells and ALMP participation

\begin{tabular}{|c|c|c|c|c|c|c|c|c|c|}
\hline & \multicolumn{2}{|c|}{$\begin{array}{l}\text { Social assistance } \\
\text { spells }\end{array}$} & \multirow{2}{*}{$\begin{array}{c}\text { ALMP spells } \\
\text { per cent }\end{array}$} & \multicolumn{2}{|c|}{$\begin{array}{l}\text { Duration of ALMP } \\
\text { subspells (months) }\end{array}$} & \multicolumn{2}{|c|}{$\begin{array}{l}\text { Duration of spell until start } \\
\text { of ALMP (months) }\end{array}$} & \multicolumn{2}{|c|}{ Spells with employment destinatior } \\
\hline & $\mathbf{N}$ & per cent & & Mean & SD & Mean & SD & $\mathrm{N}$ & per cent \\
\hline \multicolumn{10}{|l|}{ Females and males } \\
\hline Social assistance spells with ALMPs & 25,541 & 38.3 & 100.0 & 5.8 & 6.1 & 13.4 & 15.3 & 6,664 & 26 \\
\hline - Employment with wage subsidy & 1,893 & 2.8 & 7.4 & 5.3 & 4.2 & 8.6 & 10.2 & 959 & 51 \\
\hline - Direct employment programme & 6,814 & 10.2 & 26.7 & 5.7 & 6.0 & 11.2 & 13.1 & 2,273 & 33 \\
\hline - Other programmes & 16,834 & 25.2 & 65.9 & 5.9 & 6.3 & 14.8 & 16.4 & 3,432 & 20 \\
\hline Social assistance spells with no ALMP & 41,227 & 61.7 & & & & & & 15,916 & 39 \\
\hline All & 66,768 & 100.0 & & 5.8 & 6.1 & 13.4 & 15.3 & 22,580 & 34 \\
\hline \multicolumn{10}{|l|}{ Females } \\
\hline Social assistance spells with ALMPs & 11,802 & 37.8 & 100.0 & 6.3 & 6.3 & 16.2 & 17.5 & 2,575 & 22 \\
\hline - Employment with wage subsidy & 573 & 1.8 & 4.9 & 5.4 & 4.2 & 8.5 & 10.1 & 278 & 49 \\
\hline - Direct employment programme & 2,958 & 9.5 & 25.1 & 6.2 & 6.1 & 13.1 & 14.9 & 953 & 32 \\
\hline - Other programmes & 8,271 & 26.5 & 70.1 & 6.4 & 6.5 & 17.9 & 18.4 & 1,344 & 16 \\
\hline Social assistance spells with no ALMP & 19,413 & 62.2 & & & & & & 5,984 & 31 \\
\hline All & 31,215 & 100.0 & & 6.3 & 6.3 & 16.2 & 17.5 & 8,559 & 27 \\
\hline \multicolumn{10}{|l|}{ Males } \\
\hline Social assistance spells with ALMPs & 13,739 & 38.6 & 100.0 & 5.3 & 5.9 & 10.9 & 12.7 & 4,089 & 30 \\
\hline - Employment with wage subsidy & 1,320 & 3.7 & 9.6 & 5.2 & 4.3 & 8.7 & 10.2 & 681 & 52 \\
\hline - Direct employment programme & 3,856 & 10.8 & 28.1 & 5.3 & 5.9 & 9.8 & 11.3 & 1,320 & 34 \\
\hline - Other programmes & 8,563 & 24.1 & 62.3 & 5.3 & 6.0 & 11.7 & 13.6 & 2,088 & 24 \\
\hline Social assistance spells with no ALMP & 21,814 & 61.4 & & & & & & 9,932 & 46 \\
\hline All & 35,553 & 100.0 & & 5.3 & 5.9 & 10.9 & 12.7 & 14,021 & 39 \\
\hline
\end{tabular}


The baseline hazard rate is modelled flexibly by a piecewise constant function, and time-varying variables are used for modelling in- and post-programme effects of ALMPs.

Normalising the time at which immigrants begin a social assistance spell to zero, the non-negative stochastic variables $T_{u}$ and $T_{p}$ measure duration until employment and duration until programme participation, respectively. By construction, $T_{p} \leq T_{u}$. If $T_{p}<T_{u}$, the immigrant participates in a programme, and if $T_{p}=T_{u}$, he does not (the duration until participation is right-censored).

Let $x(t)$ be a vector of observed time-varying variables, and let $v_{u}$ and $v_{p}=\left(v_{p 1}, \ldots, v_{p J}\right)$ denote unobserved variables affecting the hazard rates to employment and to participation in each of the $J$ programmes, respectively. The hazard rate to participation in programme $j$ is

$$
\theta_{p j}\left(t_{p} \mid x\left(t_{p}\right), v_{p j}\right)=\lambda_{p j}\left(t_{p}\right) \exp \left(x\left(t_{p}\right) \beta_{p j}+v_{p j}\right)
$$

where $\lambda_{p j}\left(t_{p}\right)$ are piecewise constant baseline hazard rates,

$$
\lambda_{p j}\left(t_{p}\right)=\exp \left(\sum_{m=1}^{M} \gamma_{p j m} 1\left\{h_{m-1} \leq t_{p}<h_{m}\right\}\right), h_{o}=0, \quad h_{M}=\infty, \quad h_{o}<\cdots<h_{M}
$$

In this application, where the time unit is months, $h_{1}=3, h_{2}=6, h_{3}=12, h_{4}=24$. The hazard rate to programme participation is the sum of the hazard rates to the specific programmes:

$$
\theta_{p}\left(t_{p} \mid x\left(t_{p}\right), v_{p}\right)=\sum_{j=1}^{J} \theta_{p j}\left(t_{p} \mid x\left(t_{p}\right), v_{p j}\right)
$$

Participation in the $J$ different programmes is denoted by two time-varying $1 \times J$-dimensional vectors of dummy variables, $d_{1}(t)$ and $d_{2}(t)$. The $j$ th element of $d_{1}(t)$ is equal to 1 if the individual is participating in programme $j$ at time $t$, and 0 otherwise; at most, one element of $d_{1}(t)$ is equal to 1 at time $t$. Similarly, the $j$ th element of $d_{2}(t)$ is equal to 1 if the individual participated in programme $j$ before time $t$, but is no longer participating, and 0 otherwise. We only consider effects of the first programme during a social assistance spell; if a person participates in a second programme, the observation is right-censored at the time this participation begins.

The exit rate to employment is given by

$$
\theta_{u}\left(t_{u} \mid x\left(t_{u}\right), d_{1}\left(t_{u}\right), d_{2}\left(t_{u}\right), v_{u}\right)=\lambda_{u}\left(t_{u}\right) \exp \left(x\left(t_{u}\right) \beta_{u}+d_{1}\left(t_{u}\right) \delta_{1}+d_{2}\left(t_{u}\right) \delta_{2}+v_{u}\right)
$$

where the baseline hazard $\lambda_{u}\left(t_{u}\right)$ has a form similar to (2), and $\beta, \delta_{1}$ and $\delta_{2}$ are vectors of parameters; $\beta$ is the effect of the control variables, $\delta_{1}$ the in-programme effect, and $\delta_{2}$ the post-programme effect after completed programme participation. The model takes account of endogeneity of $d_{1}(t)$ and $d_{2}(t)$ through possible correlation between the unobserved variables $v_{u}$ and $v_{p}$. 
Let $c$ be a dummy variable equal to 1 if the person exits to employment and 0 otherwise; similarly, let $c_{j}=1$ if the person participates in programme $j$. Then the contribution to the likelihood function of a specific spell, given observed variables, is

$$
\begin{aligned}
L\left(v_{u}, v_{p}\right)= & {\left[\prod_{j=1}^{J} \theta_{p j}\left(t_{p j} \mid x\left(t_{p j}\right), v_{p j}\right)^{1\left\{t_{p j}<t_{u}\right\} c_{j}}\right] \theta_{u}\left(t_{u} \mid x\left(t_{u}\right), d_{1}\left(t_{u}\right), d_{2}\left(t_{u}\right), v_{u}\right)^{c} } \\
& \times \exp \left[-\int_{0}^{t_{p}} \theta_{p}\left(s \mid x(s), v_{p}\right) d s-\int_{0}^{t_{u}} \theta_{u}\left(s \mid x(s), d_{1}(s), d_{2}(s), v_{u}\right) d s\right]
\end{aligned}
$$

The likelihood function is

$$
L=\iint L\left(v_{u}, v_{p}\right) d F\left(v_{u}, v_{p}\right)
$$

where $F$ is the distribution function of $\left(v_{u}, v_{p}\right)$. We take account of the fact that a given person may have more than one social assistance spell. To simplify the estimation, we apply a discrete distribution (Heckman and Singer, 1984). Specifically, we assume that $\left(v_{u}, v_{p}\right)$ has a discrete distribution with $2 \times 2$ mass points. This implies that the unobserved components of the selection into the $J$ different programmes are perfectly correlated, but the correlation between $v_{u}$ and $v_{p}$ is unrestricted.

\subsection{Marginal effects on the hazard rate and on the duration to employment}

The marginal effects of the control variables on the hazard rate to employment are given by the coefficients $\beta_{u}$ (ignoring the effects via programme participation). Thus, the coefficient of the $h^{\text {th }}$ explanatory variable, $\beta_{u h}$, is equal to the change in the logarithm of the hazard rate to employment when this variable is changed by 1 unit holding all other variables constant. Similarly, $\delta_{1}$ and $\delta_{2}$ are the marginal in-programme and post-programme effects, respectively, of participation in labour market programmes on the log hazard rate to employment.

The total effect of participation in a specific programme on the expected duration until employment depends of course on $\delta_{1}$ and $\delta_{2}$, but also on the timing and duration of the programme and on the basic level of the hazard rate to employment (since $\delta_{1}$ and $\delta_{2}$ affect the hazard rate multiplicatively) determined by individual characteristics. We calculate the marginal effects of programme participation for a 'reference person' given a range of typical programme starting times and durations. These marginal effects are calculated as the difference in expected mean duration to employment with and without programme participation. In these calculations we use restricted mean durations, i.e. expected mean durations up to a predetermined endpoint, $T_{\max }$ (which is taken to be five years).

Let $z(t)=\left(x(t), d_{1}(t), d_{2}(t)\right)$ denote the vector of covariates. Let $z^{1}(t)$ denote the covariates when an individual is assigned to a given programme at a given time and with a given duration, and let $z^{0}(t)$ denote covariates when the individual is not assigned to any programme. Then the marginal effect of this programme is defined as the difference in restricted expected durations:

$$
M=E_{T_{\max }}\left[T_{u} \mid z^{1}(t)\right]-E_{T_{\max }}\left[T_{u} \mid z^{0}(t)\right]
$$


where the restricted expected duration is the expected area under the survivor curve up to time $T_{\max }$

$$
E_{T_{\max }}\left[T_{u} \mid z(t)\right]=E\left[\int_{0}^{T_{\max }} S(r) d r\right]
$$

and the survivor function is calculated from the hazard rate:

$$
S(t)=\exp \left(-\int_{0}^{t} \theta_{u}(s \mid z(s)) d s\right)
$$

Details on the calculation of marginal effects are described in Section 5.

\section{Data}

We use data from several administrative registers, which are collected and merged by Statistics Denmark. Our data set covers the period 1984-2004 and contains all immigrants in Denmark, but we restrict the analysis to immigrants from non-western countries.

We further restrict the sample to persons who were residents in Denmark in 1997 or 1998 due to the fact that there was a major institutional change in 1999 affecting newly arrived immigrants, and also that the administrative data on ALMP participation for immigrants who got their residence permit in 1999 are incomplete. Also, we restrict the analysis to immigrants who began a social assistance spell between January 1997 and December 2003 due to the fact that data on participation in ALMPs are only available from 1997 onwards. Finally, we restrict the analysis to social assistance spells where the immigrants were 18-66 years of age when the spell began.

The final estimation sample contains 66,768 social assistance spells, 31,215 for women and 35,553 for men; see Table 1.

The upper panel of Table 1 shows figures for both women and men. For 38\% of the social assistance spells, the immigrant is participating in an activation programme. Of those who participate in programmes, $7.4 \%$ concerns employment with a wage subsidy, and $26.7 \%$ direct employment programmes. Durations of each type of activation programme vary a lot (mean duration is 5-6 months with a standard deviation of 4-6 months), but one reason for this is that some programmes are interrupted, for instance because the participant finds a job. There is also a large variation in the time of entry into programmes: On average, immigrants who participate in a programme enter about 13 months after the start of the social assistance spell, and the standard deviation is 15 months. $34 \%$ of all the immigrant social assistance spells have employment as destination state. The percentage is 39 for spells not involving ALMP participation and 26 for spells with ALMP participation, varying from $51 \%$ for employment with wage subsidy to 20 for 'other programmes'.

The two lower panels in Table 1 show figures for women and men, separately. The fraction participating in employment programmes is larger for men, whereas the fraction participating in 'other programmes' is larger for women. The average duration of direct employment programmes and 'other programmes' is about 1 month longer for women than for men, and women are enrolled in these programmes much later than men (about 3 and 6 months later, respectively). The probability of employment as the destination state is considerably larger for men than for women, especially for social assistance spells not involving ALMP participation and for spells with participation in 'other programmes'. 
Durations of the social assistance spells are in general very long, and considerably longer for women than for men. This is illustrated in Figure 1 by non-parametric Kaplan-Meier survival functions. For women, the probability that a social assistance spell lasts at least 12, 24, 48 and 84 months is 79, 71, 61 and 54\%, respectively. For men the corresponding percentages are 67, 54, 43 and 37.

We estimate separate models for men and women. Control variables in the analyses are measured in the year where the social assistance spell began. Controls are variables for years since migration, country of origin, type of residence permit, age, whether the person has children in different age groups, whether the person is single, working experience in Denmark, type of municipality, education, health indicators based on the number of yearly doctor visits, the local unemployment rate in the commuting area of the municipality, and the calendar year in which the social assistance spell began. Appendix contains descriptive statistics for the control variables. Of particular interest are the controls for previous labour market careers in Denmark. Thus, only $17.6 \%$ of the females and $29.5 \%$ of the males had at least 1 year of working experience in Denmark, and the shares with no Danish working experience at all was 60 and 42.6\%, respectively. This in spite of the fact that more than $60 \%$ had been in Denmark for more than 5 years and about $37 \%$ for more than 10 years.

Dividing the social assistance spells by participation in ALMPs, tables in the Appendix show for females and males, respectively, the means of control variables for each type of ALMP. These tables also show two-sample $t$ test statistics of equality with the nonparticipation groups. Many of the t statistics are significant, in some cases because of substantial differences between the groups, but also because of the large sample sizes. The pattern of differences between groups is rather similar for females and males: The share with at least 5 years since migration is larger for those participating in 'other ALMPs' than in the control group of non-participants; the share of Somalis is smaller among those participating in wage subsidy and direct employment programmes than in the control group, whereas the opposite is true for 'other ALMPs'. The share of Pakistanis is smaller in all three treatment groups compared to the control group. For females, the share who are family-reunified to a refugee is smaller for wage subsidy

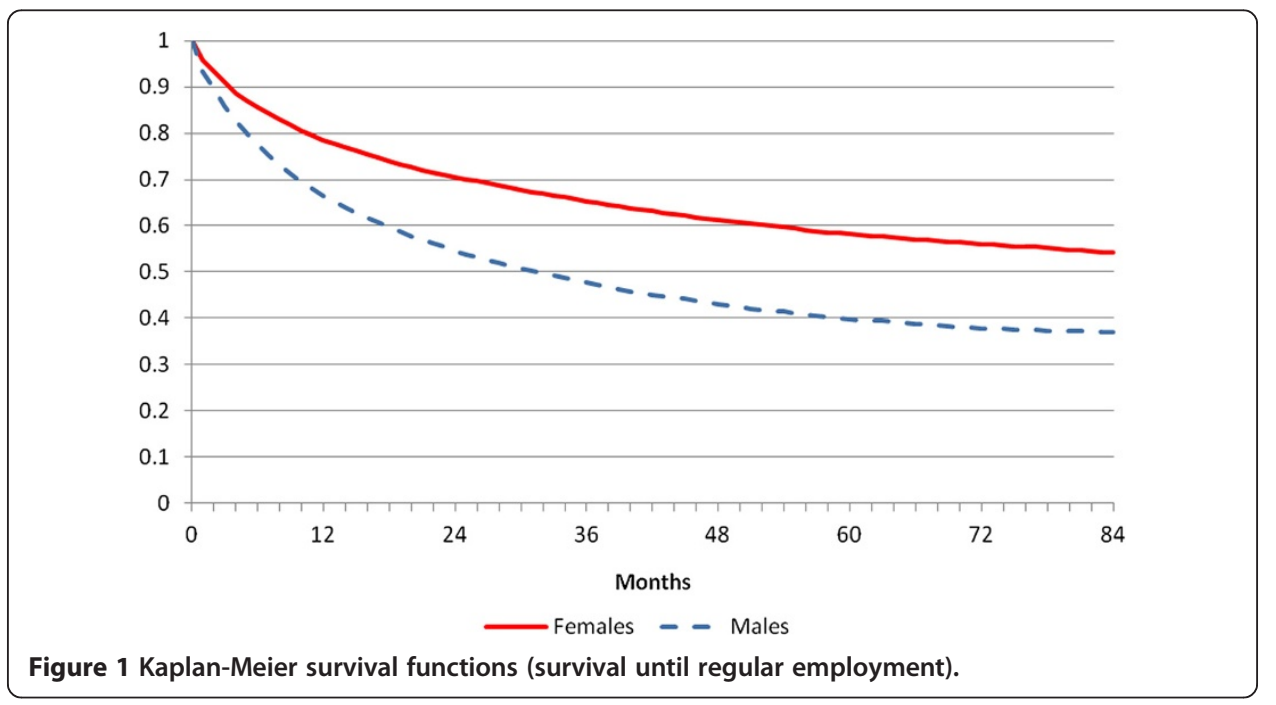


and direct employment programmes, but larger for 'other ALMPs' compared to the control group. The share with positive host country working experience is considerably smaller for direct employment and especially 'other ALMPs' compared to the control group, whereas the share with some working experience, but less than a year, is larger for wage subsidy participants than for the control group. The share living outside the metropolitan area of Copenhagen is larger among wage subsidy and direct employment participants compared to the control group, but the opposite is true for 'other ALMPs', especially for males. The share with a Danish education is smaller for 'other ALMPs' participants. The share with many GP visits is smaller among participants in wage subsidy programmes. These differences between treatment and control groups illustrate that selection into programmes is not random and need to be modelled. In the estimations we control for all the observable characteristics listed in tables of the Appendix in the hazards to employment and programme participation, and we also take account of unobserved heterogeneity as discussed in Section 3.

\section{Results}

Table 2 shows the main estimation results. The first columns show the estimation result for women, and the last columns the result for men. Table 2 shows results for parameters related to ALMP participation only. Estimated parameters of other explanatory variables are shown in the Appendix. For each of the three types of ALMPs, Table 2 shows parameter estimates for in-programme and post-programme effects. Furthermore, we allow these parameters to differ according to whether the immigrant entered the programme

Table 2 Estimates of effects of participation in ALMPs on the hazard rate to employment

\begin{tabular}{|c|c|c|c|c|c|c|}
\hline & \multicolumn{3}{|c|}{ Females } & \multicolumn{3}{|c|}{ Males } \\
\hline & Coeff. & \multicolumn{2}{|l|}{ SE } & Coeff. & \multicolumn{2}{|l|}{ SE } \\
\hline \multicolumn{7}{|c|}{ ALMP spell begins less than 6 months after start of social assistance spell } \\
\hline \multicolumn{7}{|l|}{ In-programme effects: } \\
\hline Employment with wage subsidy & -0.2394 & 0.1505 & & -0.1887 & 0.0917 & ** \\
\hline Direct employment programme & 0.4131 & 0.0702 & *** & 0.3791 & 0.0537 & *** \\
\hline Other ALMPs & 0.1693 & 0.0616 & *** & 0.1588 & 0.0446 & *** \\
\hline \multicolumn{7}{|l|}{ Post-programme effects: } \\
\hline Employment with wage subsidy & 1.4287 & 0.1333 & $* * *$ & 1.2430 & 0.0805 & *** \\
\hline Direct employment programme & 0.6844 & 0.0920 & $* * *$ & 0.3757 & 0.0718 & *** \\
\hline Other ALMPs & 0.2369 & 0.0769 & *** & 0.1240 & 0.0570 & ** \\
\hline \multicolumn{7}{|c|}{ ALMP spell begins at least 6 months after start of social assistance spell } \\
\hline \multicolumn{7}{|l|}{ In-programme effects: } \\
\hline Employment with wage subsidy & 1.3192 & 0.1786 & $* * *$ & 0.8382 & 0.1100 & *** \\
\hline Direct employment programme & 1.5442 & 0.0695 & $* * *$ & 1.0925 & 0.0607 & *** \\
\hline Other ALMPs & 0.9390 & 0.0563 & $* * *$ & 0.7245 & 0.0505 & *** \\
\hline \multicolumn{7}{|l|}{ Post-programme effects: } \\
\hline Employment with wage subsidy & 2.4127 & 0.1235 & $* * *$ & 1.8976 & 0.0738 & *** \\
\hline Direct employment programme & 1.2847 & 0.0871 & $* * *$ & 0.4565 & 0.0861 & *** \\
\hline Other ALMPs & 0.5277 & 0.0701 & $* * *$ & 0.3266 & 0.0607 & *** \\
\hline
\end{tabular}

Note: *** and ** indicate significance at the $1 \%$ and $5 \%$ level, respectively. Parameter estimates for the other explanatory variables and for the duration dependent constant terms are shown in the Appendix. 
earlier than six months after the start of the social assistance spell, or later. Thus, the table shows for each gender six estimates of in-programme effects and six estimates of post-programme effects. All estimates of post-programme effects are positive and clearly significant. Employment with a wage subsidy has the largest effect followed by direct employment programmes. For all three types of ALMPs, the post-programme effects on the hazard rate to employment are larger if the activation period begins after six months (rather than during the first six months of the social assistance spell).

Somewhat surprisingly, most in-programme effects are also positive, indicating that ALMP participation increases the hazard rate to ordinary employment also during participation. The standard finding here is one of lock-in effects during programme participation. The only exception is for subsidized employment spells which begin less than six months after the start of the social assistance spell; here we do find a lock-in effect, but it is only marginally significant. Clausen et al. (2009) also find positive, but insignificant, in-programme effects for subsidized employment programmes for newly arrived immigrants. Another surprising feature of the estimates is that the positive in-programme effect is larger than the post-programme effect for direct employment programmes and 'other programmes' beginning at least six months after the start of the social assistance spell (and for males the two types of effects are about equal in size for direct employment and 'other' programmes beginning within the first six months of the social assistance spell).

One reason why the estimated in-programme effects are positive and rather large may be that immigrants on social assistance benefits in general have weak qualifications, including weak host country language proficiency, and only a limited knowledge of the Danish labour market. Participating in ALMPs may therefore be particularly important for immigrants' employment chances, also because participation may serve as a positive signal to employers who may have more difficulties assessing the qualifications of immigrants than of natives.

The estimated parameters - and thereby the relative effects on the hazard rate to employment - are generally larger for women than for men, but the initial level of the hazard rate to employment is considerably lower for women than for men. The postprogramme parameter of subsidized employment starting after six months for women is 2.4 indicating a tenfold increase in the hazard rate to employment. The corresponding parameter for men (1.9) indicates a fivefold increase in the hazard rate. The corresponding in-programme parameters of 1.3 and 0.84 indicate increases in the hazard rate to employment of $277 \%$ and $132 \%$, respectively.

Table 3 shows the marginal effects of participation in activation programmes on the restricted mean duration to employment over a five-year period, calculated from a large

Table 3 Marginal effects of labour market programmes: Change in restricted mean duration of social assistance spells over a five-year period (measured in months)

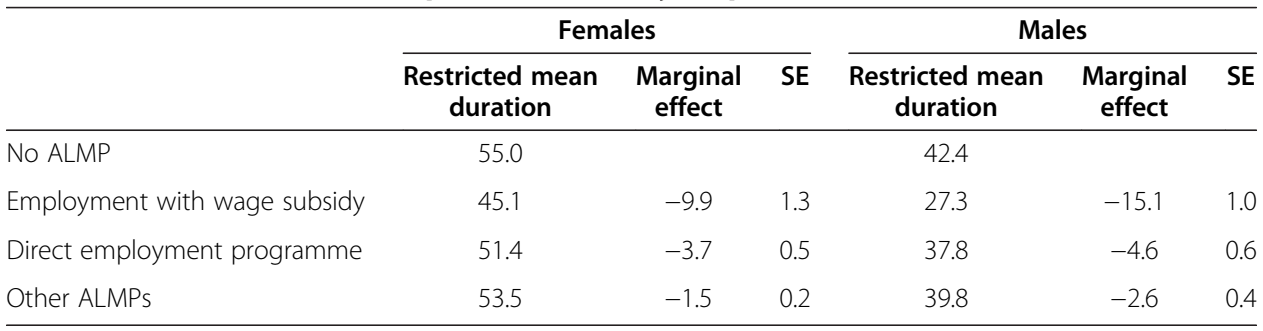

Note: The calculation of marginal effects is described in the text. 
number of typical programme spells. The effects are calculated for a 'reference person'. The characteristics chosen for this person (which affect the size of the marginal effects, but not their sign or statistical significance) are given by the reference categories of each set of categorised variables (less than 5 years since migration, from former Yugoslavia, refugee, age above 45 years, has children below 2 years of age (but no older children), cohabiting, no working experience in Denmark, lives in a big city, education unknown, 1-4 visits to the doctor, the social assistance spell began in 1997) and by the average of the local unemployment rate. If such a person did not participate in any activation programme, the restricted mean duration to employment would be 55 months for a woman and 42.4 months for a man (see the first row in Table 3). These numbers are very large; the maximum would be 60 months (given that it is restricted to be at most 5 years).

Given the values of the control variables, the restricted mean duration when participating in a given programme depends on the duration until entering the programme and the duration of the programme. Starting time and duration of a given programme vary a lot (see Table 1). Therefore, we calculate 'the' marginal effect of a given programme as an average over several typical variants of the programme defined by starting time and duration. Specifically, we use the following simplifying assumptions. Programme spells may have three different starting times and durations defined by the first, second and third quartile in the observed distributions of starting times and durations (for women and men, respectively). These quartiles are shown in Appendix. Thus, there are nine different types of a given programme, and it is assumed that each type has equal probability $1 / 9{ }^{3}$

Participation in ALMPs leads to a large reduction in the restricted mean duration to employment as shown in Table 3. Employment with a wage subsidy shortens the restricted mean duration by 10 months for women and by 15 months for men, which are very large effects. The effects of direct employment programmes and 'other ALMPs' are smaller, but also large; they reduce restricted mean durations by about 4 and 2 months, respectively. Again, the estimated effects are larger for men than for women.

The estimated marginal effects in Table 3 are clearly significant. Standard errors of the marginal effects are calculated from simulations of the estimated parameters. Given the estimated parameters and their estimated covariance matrix, we draw 500 random parameter vectors, and calculate the marginal effects for each parameter vector. The estimated standard error of the marginal effect of a given programme is the standard deviation of the 500 calculated marginal effects of this programme.

We conducted several robustness checks in terms of model specification, e.g. changing the 6 months limit in distinguishing between early and late beginning of programmes, changing the specification of control variables, and changing the specification of the piecewise-constant intervals of the baseline hazard step functions, but the main results of large and significant positive effects of ALMPs are very robust. As an illustration, the Appendix shows estimation results with a less restrictive baseline hazard function than in the main specification of Table 2, i.e. with 7 piecewise-constant intervals (instead of 5): 0-2, 2-4, 4-6, 6-9, 9-12, 12-24 and 24- months. All point estimates of in-programme and post-programme effects are even larger with this less restrictive baseline hazard than in Table 2, although for most parameters the differences are not statistically significant. 
Clausen et al. (2009) analysed effects for newly arrived immigrants in Denmark using the same methods as in this paper and found significant effects for subsidized employment (a reduction in the restricted mean duration to employment of about four months over a four-year period), but not for direct employment programmes or other programmes. There may be several explanations for the large ALMP effects which we estimate in this paper compared to Clausen et al. (2009). The effects in Table 3 are calculated over a longer time horizon (5 years instead of 4), but more importantly, the two samples of immigrants are very different. The group studied in the present paper is a much more selective group of immigrants, the majority of whom had been living in Denmark for many years and at the same time with very limited working experience in Denmark, who were older, and who had more health problems (measured by GP visits). Thus, this group of immigrants have a very weak attachment to the labour market and their basic hazard rate to employment is very low (see Figure 1). Given this weak background, ALMPs may help these immigrants to obtain more basic knowledge of the Danish labour market (and society in general) and provide contacts to firms. This is of course a general purpose of ALMPs, but it may be particularly important for groups with a very weak position in the labour market and a very limited network. In particular, this may be one of the reasons why we find positive in-programme effects and positive effects of direct employment programmes (which are often found to have small and insignificant effects for natives). The earlier study by Clausen et al. (2009) focused on all newly arrived immigrants who arrived later (from 1999 onwards) than the group studied in the present paper and received a more comprehensive 'introduction programme' including extensive courses in the Danish language and society, and regular meetings with case workers, and in addition more extensive offers of ALMPs. Therefore, the marginal effect of ALMPs may be smaller for this group which also includes a larger share with a strong commitment and ability to work (because it is not selected in terms of labour market success in the host country).

A qualitative case study (Järvinen, 2007) casts light on characteristics related to employment prospects and ALMP participation of a selected group of non-western immigrants who had been without a job and dependent on social assistance over a long period of time. The study is based on interviews with case workers and analysis of 100 case files. Although people who receive social assistance are obliged to apply for jobs and/or participate in ALMPs or other activities aiming at improving their chances of employment, these requirements may typically be more difficult to uphold for nonwestern immigrants. Thus, many non-western immigrants face social problems some of which are related to culture and norms, including traditional gender roles from their country of origin. Typically, males in this group do want to work, but many have unrealistic expectations as to which type of job they can get or which type of Danish education they are able to complete. Perceptions of gender roles are a barrier for both males and females. For instance, many males do not want to work with female colleagues, and many females do not want a job at all and try to avoid participation in ALMPs, often because their husband is against it. Another important barrier is perceptions of health problems. Many claim that they have health problems which are not confirmed by doctors, but at the same time they are not active in dealing with these problems, e.g. through change of life style. Health problems are often used as an argument to postpone participation in ALMPs, especially by women. It is likely that 
the population of this case study is representative of a significant part of the population studied in the present paper, so the characteristics discussed above may help explain why social assistance spells are very long in our data, why women are enrolled in ALMPs much later than men, and why we find large positive ALMP effects. The last feature may in part be due to possible effects of ALMP participation on overcoming cultural barriers to labour market integration.

Only few papers have estimated ALMP effects specifically for immigrants. Rinne (2012) survey studies on effects of ALMPs specifically targeted towards immigrants and also studies on effects of more general ALMPs estimated separately for immigrants and natives. Direct comparison with our results is difficult because of important differences in terms of outcome variables, types of ALMPs, types of effects and methods, but most of these studies find large and significant effects for immigrants. Sarvimäki and Hämäläinen (2010) find large positive effects on employment and earnings of a programme for immigrants consisting of a sequence of training and subsidized employment in Finland. Cohen-Goldner and Eckstein (2010) find positive employment and earnings effects of public training programs for highskilled female immigrants from the former Soviet Union in Israel. Aldashev et al. (2010) find positive effects of aptitude tests and skill provision for immigrants in Germany, whereas training programmes have no effects and job search programmes affects females negatively and have no effects for males. Caliendo and Kühn (2011) find positive effects of start-up programmes for both immigrants and natives in Germany. Bergemann et al. (2011) find positive ex ante/threat effects of ALMPs on search effort for Eastern European immigrants in Germany, whereas there is no effect for Turkish immigrants.

Comparing our results to the broader literature on effects of ALMPs on labour market outcomes (see the surveys in Stanley et al. 1999; Heckman et al. 1999; Kluve and Schmidt 2002; Kluve 2010; Card et al. 2010), the positive effect of employment with a wage subsidy on the hazard rate to regular employment is consistent with most previous studies. Our finding of significant and rather large effects for direct employment programmes is less consistent with previous findings, since most studies find only small and often insignificant effects. Our category 'other programmes', for which we find a small but significant effect, includes very different programmes such as training, special employment programmes and counselling. Most previous studies find positive effects of counselling, marginally positive effects of special employment programmes and small positive or insignificant effects of training.

\section{Discussion and conclusion}

Using the timing of events duration model and a large administrative data set, this study finds large and substantial positive effects of having participated in ALMPs on the hazard rate to regular employment for immigrants receiving social assistance in Denmark. We estimate separate effects for three categories of programmes, and we allow both in-programme and post-programme effects to differ according to whether the program began before or after 6 months. The post-programme effects are largest for subsidized employment programmes. We also find positive in-programme effects except for subsidized employment programmes starting early. Both in-programme and post-programme effects are much larger when the program begins at least six months after the start of the social assistance spell. 
The total effect of ALMP participation depends on both in-programme and postprogramme effects. To assess the overall effect, we calculate the marginal effects on the mean duration to regular employment over a five-year period, given a range of typical starting times and durations of ALMP sub-spells. Subsidized employment programmes reduce the duration of social assistance spells by 10-15 months, direct employment programmes reduce it by about 4 months, and other programmes by about 2 months.

The finding that subsidized employment is the most effective type of ALMP is consistent with an earlier study focussing on newly arrived immigrants and with other studies of ALMP effects for unemployed in general. However, this type of ALMP is by far the least frequently applied in Denmark; only 7.4\% of ALMPs offered to immigrants on social assistance are subsidized employment programmes (4.9\% for females and 9.6\% for males). Our results thus indicate that labour market integration of immigrants may be improved considerably by targeting subsidized employment programmes to unemployed immigrants.

Since we also estimate considerable positive effects of direct employment programmes and other programmes for immigrants - effects which are larger than similar effects for unemployed in general found in other studies - offering these programmes to a larger number of unemployed immigrants may also be beneficial to labour market integration and labour supply in general.

However, even though our results indicate large beneficial effects of an intensified use of ALMPs for immigrants, it may not be optimal to offer these programmes at a very early state of the unemployment/social assistance spell since our estimates indicate much larger positive effects on the hazard rate to employment if the ALMPs begin after six months of social assistance receipt. Such a decision requires weighing the costs of programmes against the saved social assistance.

In conclusion, we have found very large positive employment effects of ALMPs for non-western immigrants, suggesting a much more active role for activation policies in national strategies for integrating immigrants into the country. Also, we would definitely advocate more research on the topic.

\section{Endnotes}

${ }^{1}$ Non-western countries are defined as countries which are not Nordic, not in the EU (as of May 2004), and not the US, Canada, Australia, New Zealand, Switzerland, Andorra, Liechtenstein, Monaco, or San Marino.

2 The timing-of-events duration model has been used to evaluate ALMPs in several previous studies; see e.g., Richardson and van den Berg (2001), Bolvig et al. (2003), van den Berg et al. (2004), Abbring et al. (2005), Crépon et al. (2005), Lalive et al. (2005, 2008), Clausen et al. (2009), and Rosholm and Svarer (2008).

${ }^{3}$ Results are not sensitive to this assumption of equal weighting of the nine combinations of pre-programme and in-programme durations. If instead we calculate the probability of being in a certain cell by using the conditional distribution of in-programme duration, i.e. conditional on being in a certain quantile of the pre-programme duration, we obtain weights to the nine different combinations of durations for each programme which are different from 1 . The smallest weight is 0.67 and the largest is 1.26 , but in most cases the weights are close to 1 , and the calculated marginal effects are very similar to those reported in Table 3 using equal weighting. In all cases differences are less than 0.1 month. 


\section{Appendix}

Tables 4, 5, 6 show descriptive statistics for control variables, and Table 7 shows parameter estimates for control variables. Table 8 shows characteristics of ALMP spells used to calculate marginal effects, namely the quartiles in the distributions of duration of social assistance spells until start of programme and time spent in the programme, respectively. Table 9 shows parameter estimates of ALMP variables in an alternative model with more narrow intervals of the piecewise-constant baseline hazard step function.

Table 4 Descriptive statistics for controls

\begin{tabular}{|c|c|c|c|c|c|c|c|c|}
\hline \multirow[b]{2}{*}{ Variable } & \multicolumn{4}{|c|}{ Females } & \multicolumn{4}{|c|}{ Males } \\
\hline & Mean & SD & Min & $\operatorname{Max}$ & Mean & SD & Min & Max \\
\hline Years since migration: 5-9 & 0.248 & 0.432 & 0 & 1 & 0.232 & 0.422 & 0 & 1 \\
\hline Years since migration: 10-19 & 0.183 & 0.386 & 0 & 1 & 0.235 & 0.424 & 0 & 1 \\
\hline Years since migration: $20-$ & 0.166 & 0.372 & 0 & 1 & 0.176 & 0.381 & 0 & 1 \\
\hline From Turkey & 0.151 & 0.358 & 0 & 1 & 0.114 & 0.318 & 0 & 1 \\
\hline From Europe (except former Yugoslavia) & 0.090 & 0.286 & 0 & 1 & 0.082 & 0.274 & 0 & 1 \\
\hline From Africa (except Somalia) & 0.071 & 0.256 & 0 & 1 & 0.081 & 0.273 & 0 & 1 \\
\hline From Somalia & 0.096 & 0.294 & 0 & 1 & 0.120 & 0.325 & 0 & 1 \\
\hline From American countries & 0.021 & 0.144 & 0 & 1 & 0.017 & 0.129 & 0 & 1 \\
\hline From Afghanistan & 0.018 & 0.135 & 0 & 1 & 0.023 & 0.148 & 0 & 1 \\
\hline From Iraq & 0.076 & 0.264 & 0 & 1 & 0.118 & 0.322 & 0 & 1 \\
\hline From Iran & 0.050 & 0.218 & 0 & 1 & 0.063 & 0.243 & 0 & 1 \\
\hline From Sri Lanka & 0.037 & 0.188 & 0 & 1 & 0.025 & 0.155 & 0 & 1 \\
\hline From other Asian countries & 0.088 & 0.284 & 0 & 1 & 0.044 & 0.205 & 0 & 1 \\
\hline From Pakistan & 0.043 & 0.203 & 0 & 1 & 0.037 & 0.188 & 0 & 1 \\
\hline From Libanon & 0.059 & 0.236 & 0 & 1 & 0.087 & 0.282 & 0 & 1 \\
\hline From other countries & 0.041 & 0.199 & 0 & 1 & 0.043 & 0.203 & 0 & 1 \\
\hline Family reunified to a refugee & 0.128 & 0.334 & 0 & 1 & 0.044 & 0.204 & 0 & 1 \\
\hline Family reunified to non-refugee & 0.169 & 0.375 & 0 & 1 & 0.099 & 0.298 & 0 & 1 \\
\hline EU residence permit & 0.035 & 0.183 & 0 & 1 & 0.020 & 0.140 & 0 & 1 \\
\hline Unknown type of residence permit & 0.313 & 0.464 & 0 & 1 & 0.343 & 0.475 & 0 & 1 \\
\hline Age 16-24 & 0.215 & 0.411 & 0 & 1 & 0.189 & 0.391 & 0 & 1 \\
\hline Age $25-34$ & 0.400 & 0.490 & 0 & 1 & 0.378 & 0.485 & 0 & 1 \\
\hline Age $35-44$ & 0.264 & 0.441 & 0 & 1 & 0.309 & 0.462 & 0 & 1 \\
\hline Children 3-6 years of age & 0.194 & 0.395 & 0 & 1 & 0.122 & 0.327 & 0 & 1 \\
\hline Children 7-17 years of age & 0.205 & 0.404 & 0 & 1 & 0.123 & 0.329 & 0 & 1 \\
\hline No children & 0.321 & 0.467 & 0 & 1 & 0.531 & 0.499 & 0 & 1 \\
\hline Single & 0.331 & 0.471 & 0 & 1 & 0.423 & 0.494 & 0 & 1 \\
\hline Working experience up to 1 year & 0.224 & 0.417 & 0 & 1 & 0.279 & 0.448 & 0 & 1 \\
\hline Working experience $1-3$ years & 0.112 & 0.315 & 0 & 1 & 0.175 & 0.380 & 0 & 1 \\
\hline Working experience 3 years or more & 0.064 & 0.245 & 0 & 1 & 0.120 & 0.325 & 0 & 1 \\
\hline Lives in provincial town municipality & 0.343 & 0.475 & 0 & 1 & 0.326 & 0.469 & 0 & 1 \\
\hline Lives in a rural district & 0.113 & 0.317 & 0 & 1 & 0.097 & 0.296 & 0 & 1 \\
\hline Danish education & 0.166 & 0.372 & 0 & 1 & 0.217 & 0.413 & 0 & 1 \\
\hline Years of Danish education & 1.694 & 3.858 & 0 & 20 & 2.205 & 4.281 & 0 & 20 \\
\hline Foreign education & 0.346 & 0.476 & 0 & 1 & 0.325 & 0.468 & 0 & 1 \\
\hline
\end{tabular}


Table 4 Descriptive statistics for controls (Continued)

\begin{tabular}{lcccccccc}
\hline Years of foreign education & 3.876 & 5.656 & 0 & 18 & 3.957 & 5.962 & 0 & 18 \\
No visits to doctors & 0.150 & 0.357 & 0 & 1 & 0.241 & 0.428 & 0 & 1 \\
5-9 visits to doctors & 0.270 & 0.444 & 0 & 1 & 0.207 & 0.405 & 0 & 1 \\
10-19 visits to doctors & 0.220 & 0.414 & 0 & 1 & 0.108 & 0.310 & 0 & 1 \\
20 or more visits to doctors & 0.076 & 0.265 & 0 & 1 & 0.025 & 0.156 & 0 & 1 \\
Local unemployment rate x 10 & 0.621 & 0.150 & 0.326 & 1.361 & 0.622 & 0.150 & 0.317 & 1.361 \\
Social assistance spell began 1998 & 0.192 & 0.394 & 0 & 1 & 0.194 & 0.396 & 0 & 1 \\
Social assistance spell began 1999 & 0.178 & 0.382 & 0 & 1 & 0.191 & 0.393 & 0 & 1 \\
Social assistance spell began 2000 & 0.110 & 0.313 & 0 & 1 & 0.111 & 0.314 & 0 & 1 \\
Social assistance spell began 2001 & 0.108 & 0.311 & 0 & 1 & 0.105 & 0.307 & 0 & 1 \\
Social assistance spell began 2002 & 0.098 & 0.297 & 0 & 1 & 0.095 & 0.293 & 0 & 1 \\
Social assistance spell began 2003 & 0.090 & 0.287 & 0 & 1 & 0.080 & 0.271 & 0 & 1 \\
\hline
\end{tabular}

Note. Reference categories are: Years since migration less than five years; from former Yugoslavia; refugee; 45-66 years of age; children 0-2 years of age; married or cohabiting; no working experience (in Denmark); lives in the metropolitan area of Copenhagen or one of the three largest provincial cities in Denmark; education unknown; 1-4 visits to doctors; spell began in 1997.

Table 5 Means of controls for females by participation in ALMPs and two-sample $\mathbf{t}$ test statistics of equality with the non-participation group

\begin{tabular}{|c|c|c|c|c|c|c|c|}
\hline \multirow[b]{2}{*}{ Variable } & \multirow{2}{*}{$\begin{array}{c}\text { No ALMP } \\
\text { mean }\end{array}$} & \multicolumn{2}{|c|}{ Wage subsidy } & \multicolumn{2}{|c|}{ Direct employment } & \multicolumn{2}{|c|}{ Other ALMPs } \\
\hline & & mean & $t$ & mean & $\mathbf{t}$ & mean & $t$ \\
\hline Years since migration: 5-9 & 0.258 & 0.236 & -1.20 & 0.255 & -0.31 & 0.220 & -6.81 \\
\hline Years since migration: 10-19 & 0.192 & 0.222 & 1.68 & 0.189 & -0.32 & 0.154 & -7.78 \\
\hline Years since migration: 20- & 0.174 & 0.147 & -1.81 & 0.162 & -1.56 & 0.149 & -5.11 \\
\hline From Turkey & 0.155 & 0.144 & -0.77 & 0.139 & -2.34 & 0.147 & -1.77 \\
\hline From Europe (except former Yugoslavia) & 0.091 & 0.084 & -0.52 & 0.109 & 2.98 & 0.082 & -2.30 \\
\hline From Africa (except Somalia) & 0.074 & 0.045 & -3.18 & 0.054 & -4.37 & 0.070 & -1.16 \\
\hline From Somalia & 0.083 & 0.036 & -5.92 & 0.068 & -3.06 & 0.140 & 13.06 \\
\hline From American countries & 0.023 & 0.018 & -0.97 & 0.017 & -2.32 & 0.018 & -3.15 \\
\hline From Afghanistan & 0.017 & 0.012 & -1.09 & 0.018 & 0.46 & 0.024 & 3.73 \\
\hline From Iraq & 0.068 & 0.044 & -2.70 & 0.058 & -2.21 & 0.103 & 9.17 \\
\hline From Iran & 0.053 & 0.045 & -0.80 & 0.047 & -1.31 & 0.044 & -3.03 \\
\hline From Sri Lanka & 0.038 & 0.054 & 1.62 & 0.055 & 3.68 & 0.024 & -6.46 \\
\hline From other Asian countries & 0.093 & 0.150 & 3.78 & 0.083 & -1.82 & 0.074 & -5.38 \\
\hline From Pakistan & 0.049 & 0.015 & -6.39 & 0.029 & -5.76 & 0.037 & -4.41 \\
\hline From Libanon & 0.058 & 0.037 & -2.61 & 0.055 & -0.73 & 0.066 & 2.41 \\
\hline From other countries & 0.041 & 0.029 & -1.69 & 0.037 & -1.04 & 0.046 & 2.18 \\
\hline Family reunified to a refugee & 0.120 & 0.072 & -4.33 & 0.078 & -7.59 & 0.169 & 10.52 \\
\hline Family reunified to non-refugee & 0.175 & 0.149 & -1.73 & 0.139 & -5.19 & 0.167 & -1.69 \\
\hline EU residence permit & 0.036 & 0.019 & -2.84 & 0.020 & -5.20 & 0.038 & 0.92 \\
\hline Unknown type of residence permit & 0.334 & 0.325 & -0.43 & 0.297 & -4.04 & 0.268 & -11.06 \\
\hline Age 16-24 & 0.213 & 0.232 & 1.06 & 0.255 & 4.85 & 0.205 & -1.54 \\
\hline Age 25-34 & 0.393 & 0.404 & 0.55 & 0.370 & -2.31 & 0.428 & 5.49 \\
\hline Age $35-44$ & 0.261 & 0.273 & 0.65 & 0.283 & 2.49 & 0.264 & 0.57 \\
\hline Children 3-6 years of age & 0.188 & 0.191 & 0.20 & 0.211 & 2.91 & 0.204 & 3.20 \\
\hline Children $7-17$ years of age & 0.204 & 0.283 & 4.15 & 0.222 & 2.24 & 0.197 & -1.30 \\
\hline
\end{tabular}


Table 5 Means of controls for females by participation in ALMPs and two-sample $\mathbf{t}$ test statistics of equality with the non-participation group (Continued)

\begin{tabular}{lrrrrrrr}
\hline No children & 0.338 & 0.334 & -0.17 & 0.329 & -0.97 & 0.274 & -10.78 \\
Single & 0.329 & 0.348 & 0.93 & 0.357 & 2.96 & 0.325 & -0.70 \\
Working experience up to 1 year & 0.245 & 0.425 & 8.62 & 0.223 & -2.64 & 0.159 & -16.97 \\
Working experience 1-3 years & 0.126 & 0.156 & 1.98 & 0.100 & -4.22 & 0.078 & -12.46 \\
Working experience 3 years or more & 0.072 & 0.065 & -0.67 & 0.046 & -6.08 & 0.049 & -7.95 \\
Lives in provincial town municipality & 0.327 & 0.549 & 10.51 & 0.491 & 16.70 & 0.317 & -1.62 \\
Lives in a rural district & 0.114 & 0.146 & 2.12 & 0.186 & 9.54 & 0.085 & -7.59 \\
Danish education & 0.176 & 0.228 & 2.93 & 0.221 & 5.60 & 0.118 & -12.86 \\
Years of Danish education & 1.815 & 2.313 & 2.72 & 2.225 & 4.95 & 1.167 & -14.21 \\
Foreign education & 0.334 & 0.340 & 0.31 & 0.360 & 2.83 & 0.374 & 6.45 \\
Years of foreign education & 3.755 & 3.803 & 0.21 & 4.063 & 2.74 & 4.121 & 4.91 \\
No visits to doctors & 0.142 & 0.101 & -3.20 & 0.143 & 0.03 & 0.175 & 6.77 \\
5-9 visits to doctors & 0.274 & 0.287 & 0.68 & 0.262 & -1.37 & 0.260 & -2.33 \\
10-19 visits to doctors & 0.222 & 0.208 & -0.81 & 0.217 & -0.63 & 0.216 & -1.13 \\
20 or more visits to doctors & 0.080 & 0.045 & -3.85 & 0.074 & -1.10 & 0.069 & -3.15 \\
Local unemployment rate x 10 & 0.619 & 0.634 & 2.27 & 0.628 & 2.96 & 0.624 & 2.56 \\
Social assistance spell began 1998 & 0.187 & 0.161 & -1.63 & 0.201 & 1.74 & 0.203 & 2.98 \\
Social assistance spell began 1999 & 0.169 & 0.211 & 2.44 & 0.200 & 3.91 & 0.190 & 4.11 \\
Social assistance spell began 2000 & 0.110 & 0.122 & 0.91 & 0.115 & 0.80 & 0.107 & -0.64 \\
Social assistance spell began 2001 & 0.111 & 0.075 & -3.24 & 0.106 & -0.94 & 0.104 & -1.73 \\
Social assistance spell began 2002 & 0.103 & 0.090 & -1.06 & 0.096 & -1.15 & 0.087 & -4.04 \\
Social assistance spell began 2003 & 0.103 & 0.045 & -6.39 & 0.060 & -8.88 & 0.073 & -8.17 \\
\hline & & & & & & &
\end{tabular}

Note. The columns denoted t show the two-sample $t$ test statistics of equal means between spells characterized by participation in each of the three types of ALMPs and spells without ALMP participation.

Table 6 Means of controls for males by participation in ALMPs and two-sample t test statistics of equality with the non-participation group

\begin{tabular}{|c|c|c|c|c|c|c|c|}
\hline \multirow[b]{2}{*}{ Variable } & \multirow{2}{*}{$\begin{array}{c}\text { No ALMP } \\
\text { mean }\end{array}$} & \multicolumn{2}{|c|}{ Wage subsidy } & \multicolumn{2}{|c|}{ Direct employment } & \multicolumn{2}{|c|}{ Other ALMPs } \\
\hline & & mean & $\mathbf{t}$ & mean & $\mathbf{t}$ & mean & $\mathbf{t}$ \\
\hline Years since migration: 5-9 & 0.238 & 0.209 & -2.47 & 0.229 & -1.16 & 0.219 & -3.56 \\
\hline Years since migration: 10-19 & 0.245 & 0.226 & -1.62 & 0.233 & -1.65 & 0.210 & -6.65 \\
\hline Years since migration: 20- & 0.180 & 0.164 & -1.51 & 0.178 & -0.33 & 0.167 & -2.67 \\
\hline From Turkey & 0.119 & 0.138 & 1.94 & 0.111 & -1.40 & 0.097 & -5.60 \\
\hline From Europe (except former Yugoslavia) & 0.078 & 0.089 & 1.36 & 0.116 & 7.02 & 0.078 & -0.09 \\
\hline From Africa (except Somalia) & 0.085 & 0.063 & -3.16 & 0.056 & -7.01 & 0.084 & -0.11 \\
\hline From Somalia & 0.110 & 0.072 & -5.24 & 0.101 & -1.74 & 0.164 & 11.86 \\
\hline From American countries & 0.017 & 0.012 & -1.79 & 0.016 & -0.45 & 0.018 & 0.36 \\
\hline From Afghanistan & 0.021 & 0.021 & 0.05 & 0.021 & 0.28 & 0.029 & 3.95 \\
\hline From Iraq & 0.110 & 0.087 & -2.94 & 0.105 & -0.97 & 0.152 & 9.43 \\
\hline From Iran & 0.067 & 0.065 & -0.23 & 0.056 & -2.57 & 0.055 & -3.81 \\
\hline From Sri Lanka & 0.027 & 0.021 & -1.45 & 0.038 & 3.53 & 0.013 & -8.71 \\
\hline From other Asian countries & 0.047 & 0.033 & -2.76 & 0.049 & 0.45 & 0.035 & -4.77 \\
\hline From Pakistan & 0.040 & 0.023 & -3.95 & 0.025 & -4.97 & 0.036 & -1.67 \\
\hline From Libanon & 0.087 & 0.091 & 0.53 & 0.092 & 1.13 & 0.084 & -0.87 \\
\hline From other countries & 0.043 & 0.038 & -0.88 & 0.040 & -0.93 & 0.045 & 0.80 \\
\hline
\end{tabular}


Table 6 Means of controls for males by participation in ALMPs and two-sample $t$ test statistics of equality with the non-participation group (Continued)

\begin{tabular}{|c|c|c|c|c|c|c|c|}
\hline Family reunified to a refugee & 0.041 & 0.041 & 0.05 & 0.044 & 0.87 & 0.053 & 4.56 \\
\hline Family reunified to non-refugee & 0.104 & 0.095 & -1.12 & 0.075 & -6.28 & 0.093 & -3.09 \\
\hline EU residence permit & 0.021 & 0.015 & -1.92 & 0.013 & -4.15 & 0.020 & -0.78 \\
\hline Unknown type of residence permit & 0.355 & 0.312 & -3.28 & 0.345 & -1.13 & 0.311 & -7.40 \\
\hline Age 16-24 & 0.195 & 0.216 & 1.78 & 0.203 & 1.13 & 0.159 & -7.63 \\
\hline Age $25-34$ & 0.371 & 0.380 & 0.68 & 0.367 & -0.50 & 0.402 & 4.96 \\
\hline Age $35-44$ & 0.303 & 0.317 & 1.06 & 0.320 & 2.13 & 0.319 & 2.69 \\
\hline Children 3-6 years of age & 0.120 & 0.125 & 0.52 & 0.131 & 1.86 & 0.122 & 0.62 \\
\hline Children 7-17 years of age & 0.122 & 0.148 & 2.66 & 0.133 & 1.87 & 0.121 & -0.24 \\
\hline No children & 0.543 & 0.522 & -1.55 & 0.503 & -4.59 & 0.506 & -5.82 \\
\hline Single & 0.430 & 0.417 & -0.92 & 0.421 & -0.99 & 0.403 & -4.29 \\
\hline Working experience up to 1 year & 0.291 & 0.397 & 7.72 & 0.267 & -3.04 & 0.228 & -11.35 \\
\hline Working experience $1-3$ years & 0.189 & 0.191 & 0.18 & 0.156 & -5.14 & 0.139 & -10.95 \\
\hline Working experience 3 years or more & 0.129 & 0.129 & -0.07 & 0.107 & -4.09 & 0.095 & -8.71 \\
\hline Lives in provincial town municipality & 0.321 & 0.474 & 10.85 & 0.464 & 16.62 & 0.258 & -10.99 \\
\hline Lives in a rural district & 0.096 & 0.133 & 3.80 & 0.155 & 9.49 & 0.068 & -8.35 \\
\hline Danish education & 0.231 & 0.217 & -1.16 & 0.228 & -0.31 & 0.173 & -11.62 \\
\hline Years of Danish education & 2.352 & 2.202 & -1.24 & 2.265 & -1.17 & 1.735 & -12.00 \\
\hline Foreign education & 0.316 & 0.335 & 1.44 & 0.323 & 0.86 & 0.350 & 5.63 \\
\hline Years of foreign education & 3.850 & 4.243 & 2.25 & 3.900 & 0.48 & 4.254 & 5.24 \\
\hline No visits to doctors & 0.237 & 0.265 & 2.23 & 0.224 & -1.78 & 0.255 & 3.24 \\
\hline $5-9$ visits to doctors & 0.207 & 0.204 & -0.29 & 0.206 & -0.16 & 0.207 & 0.02 \\
\hline $10-19$ visits to doctors & 0.111 & 0.083 & -3.47 & 0.116 & 0.93 & 0.099 & -3.03 \\
\hline 20 or more visits to doctors & 0.028 & 0.017 & -2.72 & 0.021 & -2.72 & 0.021 & -3.36 \\
\hline Local unemployment rate $\times 10$ & 0.620 & 0.643 & 5.10 & 0.635 & 5.34 & 0.619 & -0.49 \\
\hline Social assistance spell began 1998 & 0.188 & 0.201 & 1.18 & 0.221 & 4.61 & 0.201 & 2.62 \\
\hline Social assistance spell began 1999 & 0.178 & 0.227 & 4.16 & 0.207 & 4.15 & 0.216 & 7.41 \\
\hline Social assistance spell began 2000 & 0.112 & 0.091 & -2.50 & 0.112 & 0.00 & 0.113 & 0.42 \\
\hline Social assistance spell began 2001 & 0.108 & 0.080 & -3.60 & 0.099 & -1.75 & 0.104 & -1.18 \\
\hline Social assistance spell began 2002 & 0.101 & 0.070 & -4.25 & 0.088 & -2.70 & 0.083 & -5.04 \\
\hline Social assistance spell began 2003 & 0.091 & 0.045 & -7.68 & 0.049 & -10.54 & 0.066 & -7.64 \\
\hline
\end{tabular}

Note. The columns denoted $t$ show the two-sample $t$ test statistics of equal means between spells characterized by participation in each of the three types of ALMPs and spells without ALMP participation.

Table 7 Estimated parameters for controls in the hazard rate to employment

\begin{tabular}{|c|c|c|c|c|c|c|}
\hline & \multicolumn{3}{|c|}{ Females } & \multicolumn{3}{|c|}{ Males } \\
\hline & Coeff. & SE & & Coeff. & SE & \\
\hline Years since migration: 5-9 & 0.276 & 0.038 & $* * *$ & 0.134 & 0.029 & $* * *$ \\
\hline Years since migration: 10-19 & 0.008 & 0.053 & & -0.102 & 0.040 & *** \\
\hline Years since migration: 20- & -0.126 & 0.050 & $* * *$ & -0.092 & 0.038 & *** \\
\hline From Turkey & -0.455 & 0.063 & $* * *$ & -0.228 & 0.049 & *** \\
\hline From Europe (except former Yugoslavia) & -0.353 & 0.060 & $* * *$ & -0.322 & 0.048 & $* * *$ \\
\hline From Africa (except Somalia) & -0.360 & 0.067 & $* * *$ & -0.267 & 0.051 & *** \\
\hline From Somalia & -0.971 & 0.071 & $* * *$ & -0.532 & 0.048 & $* * *$ \\
\hline From American countries & -0.176 & 0.094 & * & -0.275 & 0.092 & $* * *$ \\
\hline
\end{tabular}


Table 7 Estimated parameters for controls in the hazard rate to employment (Continued)

\begin{tabular}{|c|c|c|c|c|c|c|}
\hline From Afghanistan & -0.574 & 0.124 & $* * *$ & -0.249 & 0.076 & *** \\
\hline From Iraq & -0.851 & 0.076 & $* * *$ & -0.458 & 0.044 & *** \\
\hline From Iran & -0.253 & 0.075 & $* * *$ & -0.176 & 0.052 & *** \\
\hline From Sri Lanka & 0.226 & 0.077 & $* * *$ & 0.057 & 0.065 & \\
\hline From other Asian countries & -0.119 & 0.062 & * & -0.170 & 0.056 & *** \\
\hline From Pakistan & -0.676 & 0.084 & $* * *$ & -0.135 & 0.063 & ** \\
\hline From Libanon & -0.998 & 0.084 & $* * *$ & -0.485 & 0.052 & *** \\
\hline From other countries & -0.588 & 0.082 & $* * *$ & -0.388 & 0.056 & $* * *$ \\
\hline Family reunified to a refugee & -0.262 & 0.058 & $* * *$ & -0.110 & 0.063 & * \\
\hline Family reunified to non-refugee & 0.074 & 0.052 & & 0.117 & 0.044 & *** \\
\hline EU residence permit & 0.082 & 0.079 & & -0.011 & 0.079 & \\
\hline Unknown type of residence permit & -0.145 & 0.050 & $* * *$ & -0.288 & 0.037 & *** \\
\hline Age 16-24 & 1.221 & 0.061 & $* * *$ & 1.132 & 0.048 & *** \\
\hline Age $25-34$ & 1.068 & 0.050 & $* * *$ & 0.799 & 0.037 & *** \\
\hline Age 35-44 & 0.803 & 0.048 & $* * *$ & 0.475 & 0.034 & *** \\
\hline Children 3-6 years of age & 0.299 & 0.038 & $* * *$ & 0.109 & 0.032 & *** \\
\hline Children $7-17$ years of age & 0.544 & 0.042 & $* * *$ & 0.214 & 0.035 & *** \\
\hline No children & 0.415 & 0.039 & $* * *$ & 0.035 & 0.034 & \\
\hline Single & -0.163 & 0.029 & $* * *$ & -0.095 & 0.031 & *** \\
\hline Working experience up to 1 year & 1.675 & 0.035 & $* * *$ & 1.296 & 0.028 & *** \\
\hline Working experience $1-3$ years & 1.860 & 0.044 & $* * *$ & 1.667 & 0.033 & *** \\
\hline Working experience 3 years or more & 1.776 & 0.058 & $* * *$ & 1.779 & 0.042 & *** \\
\hline Lives in provincial town municipality & -0.078 & 0.032 & $* * *$ & 0.026 & 0.024 & \\
\hline Lives in a rural district & 0.111 & 0.045 & $* * *$ & 0.167 & 0.037 & $* * *$ \\
\hline Danish education & -1.536 & 0.142 & $* * *$ & -1.280 & 0.114 & $* * *$ \\
\hline Years of Danish education & 0.178 & 0.012 & $* * *$ & 0.126 & 0.010 & *** \\
\hline Foreign education & -0.420 & 0.087 & $* * *$ & -0.387 & 0.078 & *** \\
\hline Years of foreign education & 0.052 & 0.007 & $* * *$ & 0.044 & 0.006 & *** \\
\hline No visits to doctors & -0.163 & 0.043 & $* * *$ & 0.024 & 0.025 & \\
\hline $5-9$ visits to doctors & -0.083 & 0.031 & $* * *$ & -0.152 & 0.025 & *** \\
\hline $10-19$ visits to doctors & -0.346 & 0.035 & $* * *$ & -0.512 & 0.033 & *** \\
\hline 20 or more visits to doctors & -0.651 & 0.054 & $* * *$ & -0.899 & 0.067 & *** \\
\hline Local unemployment rate $\times 10$ & -0.620 & 0.135 & $* * *$ & -0.689 & 0.107 & *** \\
\hline Social assistance spell began 1998 & -0.075 & 0.044 & * & -0.117 & 0.034 & *** \\
\hline Social assistance spell began 1999 & -0.162 & 0.052 & $* * *$ & -0.211 & 0.040 & $* * *$ \\
\hline Social assistance spell began 2000 & -0.047 & 0.058 & & -0.141 & 0.045 & *** \\
\hline Social assistance spell began 2001 & -0.236 & 0.062 & $* * *$ & -0.207 & 0.049 & *** \\
\hline Social assistance spell began 2002 & -0.267 & 0.064 & $* * *$ & -0.441 & 0.051 & *** \\
\hline Social assistance spell began 2003 & -0.355 & 0.061 & $* * *$ & -0.415 & 0.048 & *** \\
\hline Duration 0-3 months & -5.432 & 0.153 & $* * *$ & -4.171 & 0.118 & *** \\
\hline Duration 3-6 months & -6.168 & 0.154 & $* * *$ & -4.931 & 0.120 & *** \\
\hline Duration 6-12 months & -6.406 & 0.152 & $* * *$ & -5.113 & 0.119 & *** \\
\hline Duration $12-24$ months & -6.751 & 0.151 & $* * *$ & -5.410 & 0.118 & *** \\
\hline Duration 24- months & -7.033 & 0.150 & $* * *$ & -5.811 & 0.118 & *** \\
\hline
\end{tabular}

Note. ${ }^{* *}, * *$ and ${ }^{*}$ indicate significance at the $1 \%, 5 \%$ and $10 \%$ level, respectively. The last five variables are the duration dependent constant terms. See the note to Table 4 for reference categories of the explanatory variables. 
Table 8 Characteristics of ALMP spells used to calculate marginal effects: Quartiles in the distributions of duration of social assistance spells until start of programme and time spent in the programme

\begin{tabular}{lcccccccc}
\hline & \multicolumn{3}{c}{ Females } & & \multicolumn{3}{c}{ Males } \\
\cline { 2 - 5 } \cline { 5 - 6 } Quartile & First & Second & Third & First & Second & Third \\
\hline Employment with wage subsidy & 2 & & 5 & 11 & 2 & 5 & 11 \\
Direct employment programme & 2 & 7 & 19 & 2 & 5 & 13 \\
Other programmes & 3 & 11 & 26 & 2 & 6 & 16 \\
Employment with wage subsidy & 3 & 5 & 7 & 3 & 5 & 7 \\
Direct employment programme & 2 & 5 & 7 & & 2 & 3 & 6 \\
Other programmes & 2 & 4 & 9 & & 2 & 3 & 6 \\
\hline
\end{tabular}

Table 9 Estimates of effects of participation in ALMPs on the hazard rate to employment in a model with more narrow intervals of the piecewise-constant baseline hazard

\begin{tabular}{|c|c|c|c|c|c|c|}
\hline & \multicolumn{3}{|c|}{ Females } & \multicolumn{3}{|c|}{ Males } \\
\hline & Coeff. & SE & & Coeff. & SE & \\
\hline \multicolumn{7}{|c|}{ ALMP spell begins less than 6 months after start of social assistance spell } \\
\hline \multicolumn{7}{|l|}{ In-programme effects: } \\
\hline Employment with wage subsidy & -0.0618 & 0.1516 & & -0.0976 & 0.0904 & \\
\hline Direct employment programme & 0.5811 & 0.0697 & $* * *$ & 0.4853 & 0.0534 & *** \\
\hline Other ALMPs & 0.2978 & 0.0626 & $* * *$ & 0.2483 & 0.0448 & *** \\
\hline \multicolumn{7}{|l|}{ Post-programme effects: } \\
\hline Employment with wage subsidy & 1.6260 & 0.1321 & $* * *$ & 1.3049 & 0.0803 & *** \\
\hline Direct employment programme & 0.8608 & 0.0903 & *** & 0.4841 & 0.0714 & *** \\
\hline Other ALMPs & 0.3720 & 0.0774 & $* * *$ & 0.2295 & 0.0571 & *** \\
\hline \multicolumn{7}{|c|}{ ALMP spell begins at least 6 months after start of social assistance spell } \\
\hline \multicolumn{7}{|l|}{ In-programme effects: } \\
\hline Employment with wage subsidy & 1.4357 & 0.1787 & $* * *$ & 0.8866 & 0.1103 & *** \\
\hline Direct employment programme & 1.6456 & 0.0687 & $* * *$ & 1.1638 & 0.0607 & *** \\
\hline Other ALMPs & 1.0102 & 0.0560 & $* * *$ & 0.7876 & 0.0506 & *** \\
\hline \multicolumn{7}{|l|}{ Post-programme effects: } \\
\hline Employment with wage subsidy & 2.5392 & 0.1264 & $* * *$ & 1.9692 & 0.0765 & *** \\
\hline Direct employment programme & 1.3905 & 0.0859 & $* * *$ & 0.5235 & 0.0863 & *** \\
\hline Other ALMPs & 0.5991 & 0.0697 & $* * *$ & 0.3844 & 0.0608 & *** \\
\hline
\end{tabular}

Note: *** indicate significance at the $1 \%$ level.

The piecewise-constant intervals of the baseline hazard step functions are less wide than in the main model (see Tables 2 and 7): 0-2, 2-4, 4-6, 6-9, 9-12, 12-24 and 24- months. 


\section{Competing interests}

The IZA Journal of Migration is committed to the IZA Guiding Principles of Research Integrity. The authors declare that they have observed these principles.

\section{Acknowledgements}

The main part of this research was conducted while Eskil Heinesen and Leif Husted were affiliated with the Danish Institute of Governmental Research (AKF/KORA). We are grateful to participants in The EALE Conference 2011, anonymous referees and the Editor Denis Fougère for helpful comments and suggestions, and to Susan Stilling for carefully editing the paper. The Danish Council for Independent Research, Social Sciences, is acknowledged with gratitude for financial support.

Responsible editor: Denis Fougère

\section{Author details}

${ }^{1}$ Rockwool Foundation Research Unit, Sølvgade 10, DK-1307, Copenhagen K, Denmark. ${ }^{2}$ SFI, The Danish National Centre for Social Research, Herluf Trolles Gade 11, 1052, Copenhagen K, Denmark. ${ }^{3}$ Aarhus University, Department of Economics and Business, and IZA, Bonn, Fuglesangs Alle 4, DK-8210, Aarhus V, Denmark.

Received: 23 October 2012 Accepted: 12 July 2013

Published: 09 Aug 2013

\section{References}

Abbring JH, van den Berg GJ (2003) The non-parametric identification of treatment effects in duration models. Econometrica 71(5):1491-1517

Abbring JH, van den Berg GJ, van Ours JC (2005) The effect of unemployment insurance sanctions on the transition rate from unemployment to employment. Econ J 115:602-630

Aldashev A, Thomsen SL, Walter T (2010) Short-term training programs for immigrants: Do effects differ from natives and why? ZEW Discussion Paper 10-021. Center for European Economic Research (ZEW), Mannheim

Bergemann A, Caliendo M, van den Berg GJ, Zimmermann KF (2011) The threat effect of participation in active labor market programs on job search behavior of migrants in Germany. Int J Manpow 32(7):777-795

Bolvig I, Jensen P, Rosholm M (2003) The employment effects of active social policy. IZA Discussion Paper No. 736. IZA, Bonn

Caliendo M, Kühn S (2011) Start-up subsidies for the unemployed: Long-term evidence and effect heterogeneity. J Public Econ 95(3-4):311-331

Card D, Kluve J, Weber A (2010) Active Labor Market Policy Evaluations: A Meta-Analysis. Econ J 120:F452-F477

Clausen J, Heinesen E, Hummelgaard H, Husted L, Rosholm M (2009) The effect of integration policies on the time until regular employment of newly arrived immigrants: Evidence from Denmark. Labour Econ 16:409-417

Cohen-Goldner S, Eckstein Z (2010) Estimating the return to training and occupational experience: The case of female immigrants. J Econ 156(1):86-105

Crépon B, Dejemeppe M, Gurgand M (2005) Counselling the unemployed: does it lower unemployment duration and recurrence? IZA Discussion Paper No. 1796. IZA, Bonn

Heckman JJ, Lalonde RJ, Smith JA (1999) The economics and econometrics of ALMP. Handbook of Labor Economics 3:1865-2097. North-Holland, Amsterdam

Heckman JJ, Singer B (1984) A method for minimizing the impact of distributional assumptions in econometric models for duration data. Econometrica 52(2):271-320

Järvinen M (2007) Fra klientgørelse til selvforvaltning - socialt arbejde med etniske minoritetsklienter (From clientisation to self management - social work with ethnic minority clients). In: Nielsen VL, Ploug N (ed) Når politik bliver til virkelighed (When politics become reality). SFI - The Danish National Centre for Social Research, Copenhagen

Kluve J, Schmidt C (2002) Can training and employment subsidies combat European unemployment? Economic Policy 35:411-448

Kluve J (2010) The effectiveness of European active labor market programs. Labour Econ 17:904-918

Lalive R, van Ours JC, Zweimüller J (2005) The effect of benefit sanctions on the duration of unemployment. J Eur Econ Assoc 3(6):1-32

Lalive R, van Ours JC, Zweimüller J (2008) The impact of active labour market programmes on the duration of unemployment in Switzerland. Econ J 118:235-257

OECD (2005) Trends in International Migration. Annual Report, 2004 Edition. OECD, Paris

Pedersen S (2000) Overførselsindkomster til indvandrere (Transfer income to immigrants). In: Mogensen GV, Matthiessen PC (ed) Integration i Danmark omkring årtusindskiftet (Integration in Denmark at the turn of the millennium). Aarhus Universitetsforlag, Rockwool Foundation Research Unit

Richardson K, van den Berg GJ (2001) The effect of vocational employment training on the individual transition rate from unemployment to work. Swedish Economic Policy Review 8(2):175-213

Rinne U (2012) The evaluation of immigration policies. In: Zimmermann KF, Constant A (ed) IZA Discussion Paper No. 6369, forthcoming in. International Handbook on the Economics of Migration, Edward Elgar Publishing, Cheltenham, UK

Rosholm M, Svarer M (2008) The threat effect of active labour market programmes. Scand J Econ 110(2):385-401

Sarvimäki M, Hämäläinen K (2010) Assimilating immigrants: The impact of an integration program. HECER Discussion Paper 306, Helsinki Center of Economic Research. Helsinki Center of Economic Research, Helsinki

Stanley M, Katz L, Krueger A (1999) Impacts of Employment and Training Programmes: The American Experience. Harvard University, Draft

van den Berg GJ, van der Klaauw B, van Ours JC (2004) Punitive sanctions and the transition rate from welfare to work. J Labor Econ 22(1):211-241

10.1186/2193-9039-2-15

Cite this article as: Heinesen et al: The effects of active labour market policies for immigrants receiving social assistance in Denmark. IZA Journal of Migration 2013, 2:15 